\title{
Gastrointestinal Bleeding due to Angiodysplasia in a Patient with Severe Aortic Stenosis: Heyde's Syndrome
}

\author{
Felipe Homem Valle1, Fernando Pivatto Júnior², Luiz Carlos Corsetti Bergoli³, \\ Rodrigo Vugman Wainstein ${ }^{4}$, Marco Vugman Wainstein ${ }^{5}$
}

\begin{abstract}
There is a frequent association between aortic valve stenosis and gastrointestinal bleeding, also known as Heyde's syndrome. The pathophysiologic basis for this syndrome seems to be an acquired von Willebrand factor deficiency, leading to bleeding of angiodysplastic arteriovenous malformations. Treatment options include the location and cauterization of bleeding points, which is associated to high recurrence rates. Valve replacement appears to offer the best hope of long-term resolution of bleeding, and should be considered in most cases. We report a 79 year-old patient with aortic stenosis and gastrointestinal bleeding due to duodenal angiodysplasia treated by transcatheter aortic valve implantation.
\end{abstract}

DESCRIPTORS: Aortic valve stenosis. Gastrointestinal hemorrhage. Angiodysplasia. Heart valve prosthesis implantation.

$\mathrm{H}$ eyde'ssyndrome, an association between aortic stenosis and gastrointestinal bleeding, was first described by Edward Heyde in 1958, ${ }^{1}$ in a series of ten patients with aortic stenosis and gastrointestinal bleeding of unknown cause, and the association with intestinal angiodysplasia was only established subsequently. Gastrointestinal bleeding appears to be caused by acquired von Willebrand disease type $2 \mathrm{~A}$, characterized by a reduction in high molecular weight multimers of von Willebrand factor (VWF). These multimers are important to maintain hemostasis in situations of high shear stress - predominant flow conditions in patients

\section{RESUMO}

\section{Sangramento Gastrintestinal por Angiodisplasia} e Estenose Aórtica: Síndrome de Heyde

Existe uma associação frequente entre estenose valvar aórtica e sangramento gastrintestinal, também conhecida como síndrome de Heyde. A base fisiopatológica dessa síndrome parece ser uma deficiência adquirida do fator de von Willebrand, que leva ao sangramento de malformações arteriovenosas angiodisplásicas. As alternativas de tratamento incluem a localização de pontos de sangramento e a cauterização, mas tal opção terapêutica está associada a alta recorrência. A substituição da válvula parece oferecer a melhor esperança de resolução a longo prazo do sangramento e deve ser considerada na maioria das vezes. Relatamos aqui o caso de uma paciente de 79 anos com estenose aórtica e sangramento gastrintestinal devido à angiodisplasia duodenal, tratada por implante transcateter de válvula aórtica.

DESCRITORES: Estenose da valva aórtica. Hemorragia gastrointestinal. Angiodisplasia. Implante de prótese de valva cardíaca.

with angiodysplastic lesions. ${ }^{2}$ Valve replacement appears to offer the best hope for a long-term resolution of bleeding, and should beconsidered in most cases. ${ }^{3}$ The case of a patient with severe aortic stenosis and gastrointestinal bleeding due to duodenal angiodysplasia is reported, successfully treated by transcatheter aortic valve implantation.

\section{CASE REPORT}

Female patient, 79 years, with severe aortic stenosis (valve area of $0.6 \mathrm{~cm}^{2}$; maximum transvalvular gradient

\footnotetext{
${ }^{1}$ Resident physician at the Cardiology Service of Hospital de Clínicas de Porto Alegre. Porto Alegre, RS, Brazil.

2 Resident physician at the Cardiology Service of Hospital de Clínicas de Porto Alegre. Porto Alegre, RS, Brazil.

${ }^{3}$ Hired physician at the Cardiology Service of Hospital de Clínicas de Porto Alegre - Unidade de Hemodinâmica. Porto Alegre, RS, Brazil.

${ }^{4}$ Master in Cardiology. Hired physician at the Cardiology Service of Hospital de Clínicas de Porto Alegre - Unidade de Hemodinâmica.

Porto Alegre, RS, Brazil.
}

\footnotetext{
${ }^{5}$ Adjunct professor of Faculdade de Medicina da Universidade Federal do Rio Grande do Sul. Porto Alegre, RS, Brazil.

Correspondence to: Felipe Homem Valle. Serviço de Cardiologia do Hospital de Clínicas de Porto Alegre. R. Ramiro Barcelos, 2.350 - Bairro Rio Branco - Porto Alegre, RS, Brazil - CEP 90035-903

E-mail: felipehvalle@gmail.com
}

Received on: 7/7/13 • Accepted on: 8/31/13 
of $96 \mathrm{mmHg}$ and mean of $59 \mathrm{mmHg}$; and preserved left ventricular systolic function) was hospitalized for symptomatic heart failure associated with melena. On admission, hemoglobin level was $4.6 \mathrm{~g} / \mathrm{dL}$. She was initially submitted to endoscopic gastrointestinal tract assessment, which showed no alterations, and colonoscopy, which showed diverticular disease of the colon, with no evidence of recent bleeding. After receiving transfusion of packed red blood cells, she achieved partial symptom improvement.

After the case study, it was decided to perform the transcatheter aortic stenosis treatment. A 23-mm Edwards SAPIEN XT valve (Edwards Life Sciences - Irvine, USA) was implanted by transfemoral route. The procedure was successfully performed without complications, resulting in aortic transvalvular gradient of $10 \mathrm{mmHg}$ with no significant aortic regurgitation (Figure 1). Two days after the procedure, there was recurrence of melena. At that time, it was decided to evaluate the small bowel by enteroscopy, for clarification of the bleeding site. The enteroscopy evaluated the bowel up to the medium jejunum, showing angiodysplastic lesion in the proximal duodenum (Figure 2), which was cauterized with an argon plasma catheter. The patient
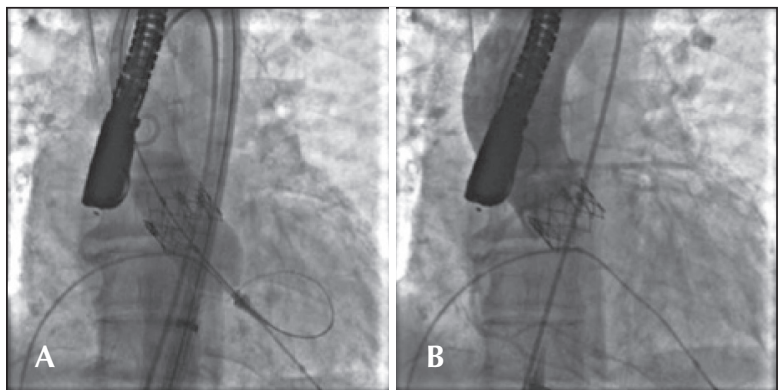

Figure 1 - (A) Release of Edwards SAPIEN XT valve after inflating the balloon catheter. (B) Implanted aortic valve.

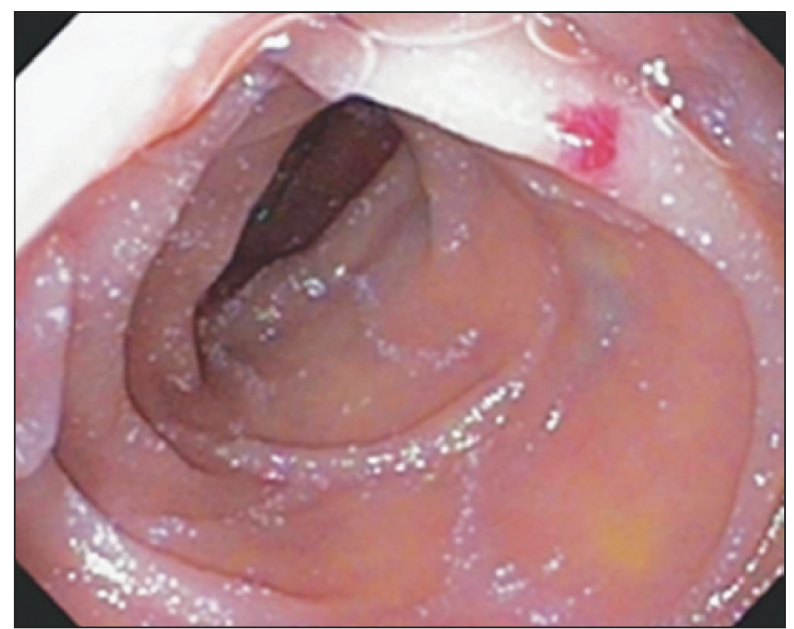

Figure 2 - Angiodysplastic lesion in the proximal duodenum. was discharged to be followed by her cardiologist in good clinical conditions, with hemoglobin of $8.2 \mathrm{~g} / \mathrm{dL}$, 21 days after admission. She was using acetylsalicylic acid (ASA) $100 \mathrm{mg} /$ day and clopidogrel $75 \mathrm{mg} /$ day was prescribed (dual antiplatelet therapy), after the absence of intestinal bleeding recurrence was confirmed, seven days after discharge.

\section{DISCUSSION}

Intestinal angiodysplasia and aortic stenosis are usually asymptomatic chronic-degenerative diseases, whose prevalence increases with age. Both are associated with cardiovascular risk factors. Many studies suggest that there is a greater occurrence of intestinal stenosis in subjects with aortic angiodysplasia, and vice versa. ${ }^{4}$ The main concept behind this association is based on the fact that both angiodysplasia intestinal and aortic stenosis are related to the physiological processes of aging. ${ }^{5}$

In 1992, an etiopathogenic mechanism was proposed by Warkentin et al., ${ }^{2}$ according to which the acquired deficiency of high molecular weight multimers of VWF (von Willebrand disease type 2A), necessary to maintain hemostasis in high-flow conditions, ${ }^{4}$ as occurs in arteriovenous angiodysplastic malformations, appeared to be the connection between the two components of this syndrome. The VWF is secreted by endothelial cells into the blood, contributing to platelet thrombus formation and acting as a mediator of platelet adhesion at the site of vascular injury. ${ }^{6}$ The high shear stress caused by the stenotic valve results in changes in the $\mathrm{VWF}^{5}$ molecule structure and subsequent proteolysis of the high molecular weight multimers by ADAMTS13 enzyme. The multimers with reduced size are, from the hemostatic point of view, less competent than the intact large multimers. This hypothesis is supported by the fact that the change of the stenotic aortic valve results in long-term resolution of digestive bleeding. In summary, the development of the acquired von Willebrand disease type $2 \mathrm{~A}$ due to aortic stenosis causes hemostatic abnormalities, which predispose to intestinal angiodysplastic bleeding, previously subclinical. ${ }^{5}$

A study by Vincentelli et al. ${ }^{7}$ demonstrated that the degree of aortic stenosis is proportional to hemostatic changes: the higher the gradient pressure, the lower the availability of high molecular weight multimers. In this study, the aortic valve replacement ceased the depletion of these multimers, and this effect has been observed in some patients as soon as the first postoperative day. ${ }^{5}$

Regarding gastrointestinal bleeding due to intestinal angiodysplasia, the options for treatment include the location and cauterization of lesions; however, these strategies are associated with high rate of recurrence. The improvement in hematological alterations after aortic valve replacement has been described and is also accompanied by clinical improvement: this approach 
seems to offer the best prospects for long-term resolution of bleeding and should be considered in most cases, especially those with symptomatic aortic stenosis. For patients at high surgical risk, in which no bleeding point was identified, the treatment of anemia with regular blood transfusions can provide some symptomatic relief. ${ }^{4}$

Aortic valve replacement appears to reduce the risk of gastrointestinal hemorrhage in patients with Heyde's syndrome, resolving the condition in approximately $80 \%$ of cases. Although the rates of bleeding recurrence are not significantly different between biological and mechanical valves, the increased risk of bleeding in patients receiving anticoagulants makes biological valves the choice for most patients. ${ }^{8}$ Bleeding recurrence occurs only when the physiopathological mechanism is restored, either by aortic restenosis or by patientprosthesis mismatch (effective valvearea/bodysurface $<0.85 \mathrm{~cm}^{2} / \mathrm{m}^{2}$ on echocardiography), with elevated gradients persisting postoperatively even with normal functioning valves. ${ }^{7}$

This case report is the second article that addresses the percutaneous treatment of aortic stenosis in patients with Heyde's syndrome. ${ }^{9}$ Godino et al. ${ }^{9}$ reported that this syndrome was present in $1.7 \%$ of 400 patients undergoing transcatheter aortic valve implantationat their institution, and that the recurrence of gastrointestinal bleeding was abolished in all successfully treated patients.

\section{CONFLICTS OF INTEREST}

Marco Vugman Wainsteinis a consultant for Biotronik, B Braun, and Terumo; board member of A esculap B Braun; researcher for Biotronik; and lector for Biosensors, B Braun, Terumo, and Astra Zeneca; he also receives scientific support from Abbott Vascular, Cordis J\&J, and Boston Scientific. The remaining authors declare to have no conflicts of interests.

\section{REFERENCES}

1. Heyde EC. Gastrointestinal bleeding in aortic stenosis. N Engl J Med. 1958;259:196.

2. Warkentin TE, Moore JC, Morgan DG. Aortic stenosis and bleeding gastrointestinal angiodysplasia: is acquired Von Willebrand's disease the link? Lancet. 1992;340(8810):35-7.

3. Morishima A, Marui A, Shimamoto T, Saji Y, Tambara K, Nishina T, et al. Successful aortic valve replacement for Heyde syndrome with confirmed hematologic recovery. Ann Thorac Surg. 2007;83(1):287-8.

4. Pate GE, Chandavimol M, Naiman SC, Webb JG. Heydes syndrome: a review. J Heart Valve Dis. 2004;13(5):701-12.

5. Vaz A, Correia A, Martins B, Capelo J, Ferreira P, Henriques P, et al. Heyde syndrome: The link between aortic stenosis and gastrointestinal bleeding. Rev Port Cardiol. 2010;29(2):309-14.

6. Figuinha FCR, Spina GS, Tarasoutchi F. Heyde's syndrome: case report and literature review. Arq Bras Cardiol. 2011;96(3): e42-5.

7. Vincentelli A, Susen S, Le Tourneau T, Six I, Fabre O, Juthier F, et al. Acquired von Willebrand syndrome in aortic stenosis. N Engl J Med. 2003;349(4):343-9.

8. Thompson JL, Schaff HV, Dearani JA, Park SJ, Sundt TM, Suri RM, et al. Risk of recurrent gastrointestinal bleeding after aortic valve replacement in patients with Heyde syndrome. J Thorac Cardiovasc Surg. 2012;144(1):112-6.

9. Godino C, Lauretta L, Pavon AG, Mangieri A, Viani G, Chieffo A, et al. Heyde's syndrome incidence and outcome in patients undergoing transcatheter aortic valve implantation. J Am Coll Cardiol. 2013;61(6):687-9. 